DOI https://doi.org/10.18551/rjoas.2018-12.01

\title{
THE SYSTEMATIC RISK OF STOCKS: ANALYSIS OF PROPERTY AND AGRICULTURE SECTOR IN INDONESIA
}

\author{
Maulana Mohamad Iqbal ${ }^{\star}$, Irawan Tony, Maulana Tb. Nur Ahmad \\ School of Business, Bogor Agricultural University, Indonesia \\ *E-mail: mohamadiabal maulana@yahoo.co.id
}

\begin{abstract}
Systematic risk is a risk that cannot be avoided and eliminated by diversification, the fluctuation of this risk is influenced by macroeconomic factors. This study aims to analyze the effect of Degree of Economic Leverage (DEL), Degree of Operating Leverage (DOL), and Degree of Financial Leverage (DFL) on the property and agriculture sector in Indonesia. In this study, researcher used secondary data; those are weekly common stock return and weekly market return published by Indonesia Stock Exchange, for determining beta coefficients. Subsequently, sales, EBIT, EAT, and annual inflation are utilized to calculate DEL, DOL, and DFL. Samples were taken by using purposive sampling and sample selection criteria. This research used panel data regression analysis using E-views 9 . The result of this research showed that (1) partially, only the variable DEL and DFL that influence significantly to systematic risks of stock on a property sector and (2) partially, only the variable DEL and DOL that influence significantly to systematic risks of stock on sector of agriculture. Therefore, investors should invest in property sector companies that have a low value of DEL, DOL, and DFL to minimize systematic risk of stocks. And in the agriculture sector companies investors should invest in companies that have a high value of DEL, DOL, and DFL to minimize the systematic risk of stocks.
\end{abstract}

\section{KEY WORDS}

Systematic risk, economic leverage, operating leverage, financial leverage, property, agriculture.

For investors, stock investing in Indonesia Stock Exchange is full of uncertainty. This uncertainty is indicated by the fluctuation of stock prices. In this regard, one of the efforts that investors can take to maximize profits from their stock investment is to consider the level of risk of their investment as the basis for making investment decisions.

The risks faced by investors in stock investments are divided into two types of risks, those are systematic risk and non-systematic risk. Non-systematic risk can be controlled by investors by diversifying portfolios, so when investors evaluating stock investment risk, they will tend to pay attention to systematic risks that can't be controlled or eliminated through portfolio diversification.

There have been several studies that have been carried out concerning the factors that influence the systematic risk of stocks, including research conducted by Harry F. Griffin and Michael T. Dugan (2003) and Putri Hervie Karuniandari (2006). The two researchers conducted a systematic risk research of stocks in the manufacturing sector. After observed the movement of the average value of stock systematic risk during the study period as reflected in Figure 1, it turns out that there are several other sectors outside the manufacturing sector that have extreme systematic risk values. The research conducted by the two researchers needs to be carried out by expanding the research to cover other sectors, including the property sector and the agriculture sector.

Based on the statement above, the research on the factors that influence the systematic risk of stocks needs to be further investigated and re-tested, so that the factors that influence the systematic risk of stocks in Indonesia will be known. 


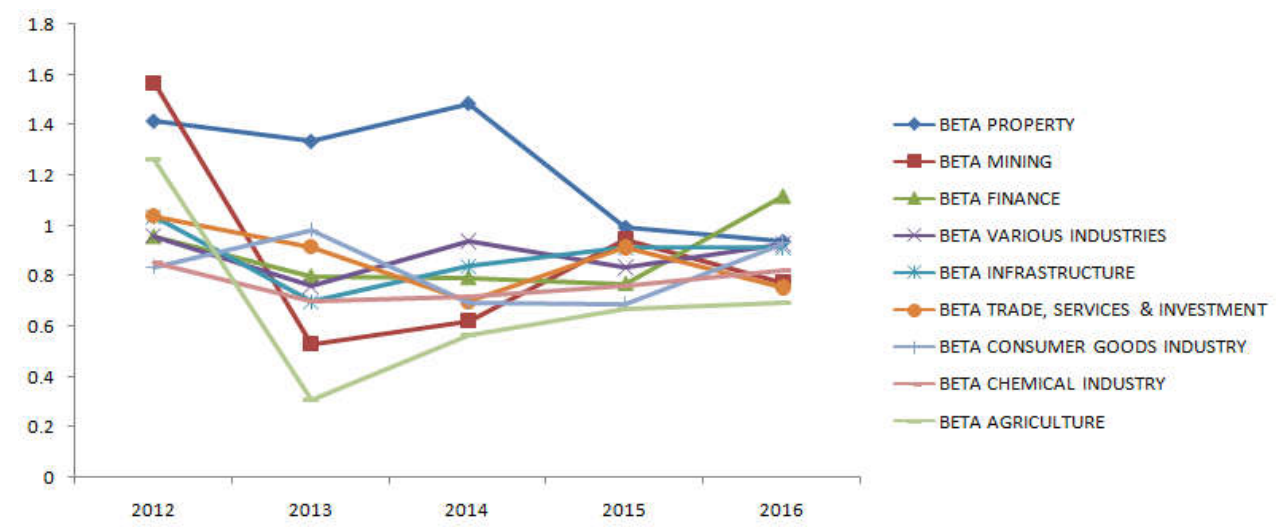

Figure 1 - Stocks beta of all sectors listed on the IDX in 2012-2016 (Source: www.investing.com, Data processed, 2017

\section{METHODS OF RESEARCH}

The data needed in this study are quantitative and secondary data, data are time series data in a period of 5 years, starting from 2012 to 2016 . Secondary data is obtained through literature studies, journals related to this research, Central Agency on Statistics (Badan Pusat Statistik), Indonesia Stock Exchange (www.idx.co.id), www.finance.yahoo.com, www.investing.com, and others.

Determination of the sample in this study was using purposive sampling focused on property sector companies and companies in the agriculture sector listed on Indonesia Stock Exchange that are actively traded from 2012 to 2016. The companies used as research samples are companies that publish their financial statements during the period of 2012 to 2016, the company has a positive beta value and is not greater than 3 , and the company has positive EBIT and EAT values. Based on these criteria, 25 companies, 20 property sector companies and 5 agriculture sector companies were obtained. The consideration of using property sector companies is to have the highest average value of systematic risk, while the consideration of using agriculture sector companies is to have the lowest average systematic risk value.

Panel data regression analysis was performed using E-views software 9. The independent variables used for panel data regression analysis in this study were DEL, DOL, and DFL, while the dependent variable is beta stock $(\beta)$. The general formula used in this study is as follows:

$$
\beta_{j}=\gamma_{0}+\gamma_{1} \mathrm{DOL}_{\mathrm{j}}+\gamma_{2} \mathrm{DFL}_{\mathrm{j}}+\gamma_{3} \mathrm{DEL}_{\mathrm{j}}+\tilde{\mathrm{e}}_{\mathrm{j}}
$$

Where: $B=$ systematic risk (stock beta); $Y_{0}=$ intercept (constant) regression equation; $Y_{1}, Y_{2}$, $Y_{3}=$ regression coefficient; $\tilde{e}_{\mathrm{j}}=$ confounding variable outside the model.

The dependent variable used in this study is stock beta. According to Bodie et al (2008), the formula used to calculate the stock beta value is as follows:

$$
\beta_{i}=\frac{\operatorname{Cov}\left(\mathrm{R}_{\mathrm{i}}, \mathrm{R}_{\mathrm{m}}\right)}{\operatorname{Var}(\mathrm{Rm})}
$$

Where: $\beta_{i}=$ Beta; $\operatorname{Cov}\left(\mathrm{R}_{\mathrm{i}}, \mathrm{R}_{\mathrm{m}}\right)=$ Covariant return of the issuer to market return; $\operatorname{Var}(\mathrm{Rm})=$ market variant

The independent variables used in this study are:

DEL. According to Mandelker and Rhee (1984), the formula used to calculate the DEL value is as follows:

$$
\mathrm{DEL}=\frac{\% \Delta Q}{\% \Delta Z}
$$


Where: $\% \Delta Q=$ Percentage change of company's sales; $\% \Delta Z=$ Percentage of changes in macroeconomic factors.

DOL. The formula used to calculate the DOL value is as follows:

$$
\text { DOL }=\frac{\% \Delta \text { EBIT }}{\% \Delta \text { Sales }}
$$

Where: $\% \Delta \mathrm{EBIT}=$ Percentage change of company's $\mathrm{EBIT}$ value $\% \Delta$ Sales $=$ Percentage change of company's sales.

DFL. The formula used to calculate the DFL value is as follows:

$$
\mathrm{DFL}=\frac{\% \Delta \mathrm{EAT}}{\% \Delta \mathrm{EBIT}}
$$

Where: $\% \Delta \mathrm{EAT}=$ Percentage change of company's $\mathrm{EAT}$ value; $\% \Delta \mathrm{EBIT}=$ Percentage change of company's EBIT value.

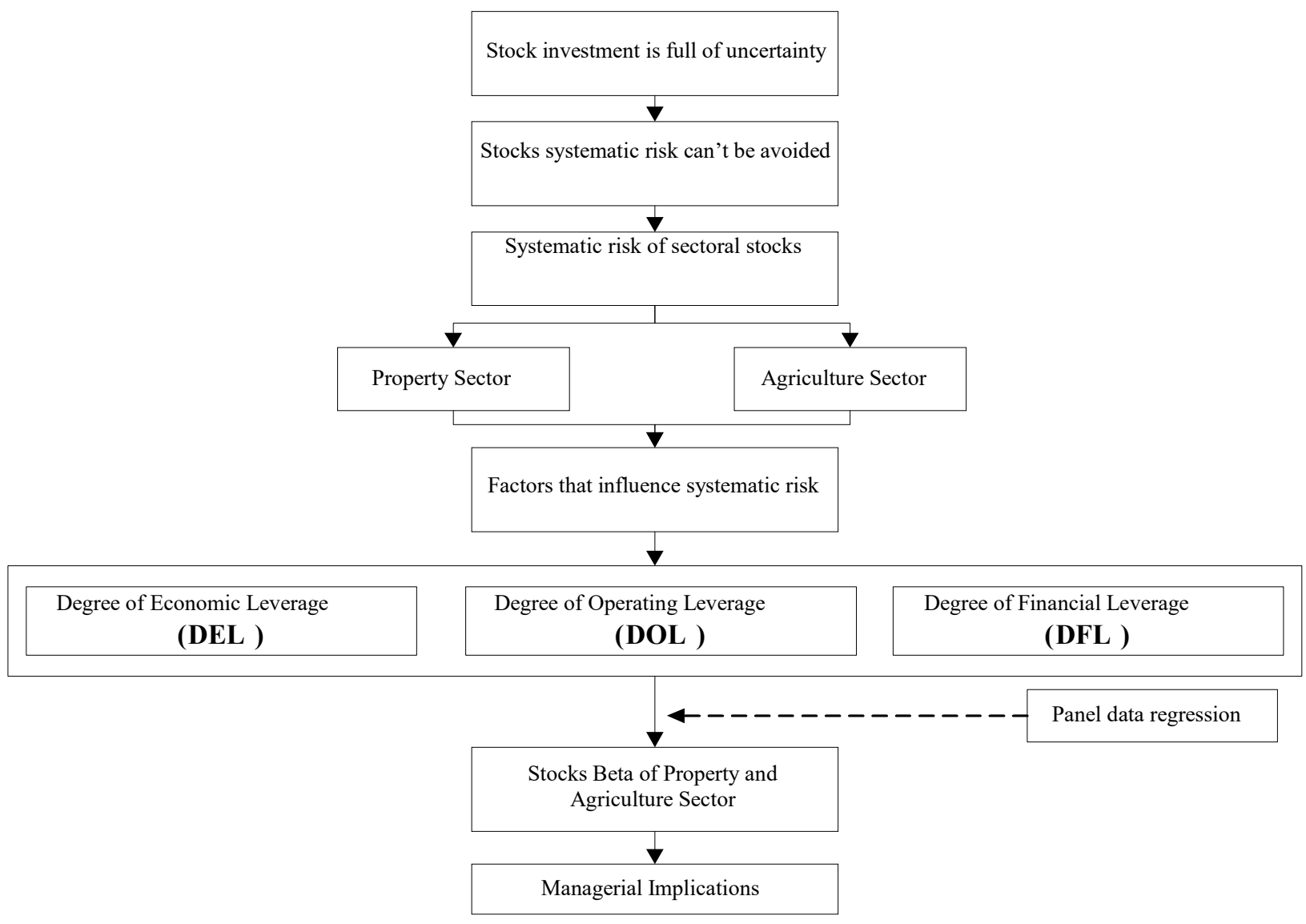

Figure 2 - Research conceptual framework

Research Hypothesis. Hypothesis formulated in this research are the influence of DEL, $\mathrm{DOL}$, and DFL on the systematic risk of stocks in property and agriculture sector companies. The hypothesis in this research can be seen as follows.

Ho.1: DEL does not affect the systematic risk of shares in the property and agricultural sector companies positively.

Ha.1: DEL affects the systematic risk of shares in the property and agricultural sector companies positively.

Ho.2: DOL does not affect the systematic risk of shares in the property and agricultural sector companies positively. 
Ha.2: DOL affects the systematic risk of shares in the property and agricultural sector companies positively.

Ho.3: DFL does not affect the systematic risk of shares in the property and agricultural sector companies positively.

Ha.3: DFL affects the systematic risk of shares in the property and agricultural sector companies positively.

\section{RESULTS AND DISCUSSION}

The process of selecting panel data regression models in this study was carried out in stages. The first step is to estimate the pooled least square (PLS) model and the fixed effect model, applied to both in the property sector companies and in the agriculture sector companies. The second step is to do the Chow test to choose the best PLS model or fixed effect model in estimating panel data regression. The following table results from the Chow test on property and agriculture sector companies.

Table 1 - Chow test results in property and agriculture sectors

\begin{tabular}{|c|c|c|c|}
\hline Cross-section F & Statistic & d.f. & Prob. \\
\hline Property & 0.898659 & $(19,77)$ & 0.5858 \\
\hline Agriculture & 0.883548 & $(4,17)$ & 0.4946 \\
\hline
\end{tabular}

Based on the test results, it showed that the $F$ value calculated on the model of property sector $(0.5858)$ and agriculture $(0.4946)$ greater than 0.05 , so the model used for the two companies is the PLS model.

The third stage is to estimate the random effect model in the property and agriculture sector companies. The fourth step is to test the Lagrange multiplier (LM) to choose the PLS model or the best random effect model in estimating panel data regression.

Table 2 - Lagrange multiplier test results for property and agriculture sectors

\begin{tabular}{|c|c|c|c|}
\hline \multirow{2}{*}{ Breusch-Pagan } & \multicolumn{3}{|c|}{ Test Hypothesis } \\
\cline { 2 - 4 } & Cross-section & Time & 37.62434 \\
\hline \multirow{2}{*}{ Property } & 0.200416 & 37.42393 & $(0.0000)$ \\
\cline { 2 - 4 } & $(0.6544)$ & $(0.0000)$ & 6.924751 \\
\cline { 2 - 4 } Agriculture & 0.294340 & 6.630411 & $(0.0085)$ \\
\hline
\end{tabular}

Based on the test results showed the probability value of Breusch-Pagan in property sector company model $(0.6544)$ and agriculture $(0.5875)$ is greater than 0.05 , so the model used for the two companies is the PLS model.

Based on the test results above, it can be concluded that the panel data regression model is the best and the model that will be used in this study for both property and agriculture sector companies is the PLS model.

Table 3 - Panel data regression model on property sector companies

\begin{tabular}{llllll}
\hline Model & R-Squared & Variable & Coefficient & Std Error & Prob \\
\hline PLS & 0.0314 & DEL & 0.00414 & 0.00061 & $\mathbf{0 . 0 0 0 0}^{*}$ \\
& & DOL & 0.00827 & 0.00535 & 0.1256 \\
& & DFL & 0.00961 & 0.00289 & $\mathbf{0 . 0 0 1 3}^{*}$ \\
\hline FEM & 0.2072 & DEL & 0.00519 & 0.00135 & $\mathbf{0 . 0 0 0 2}^{*}$ \\
& & DOL & -0.00013 & 0.00839 & 0.9871 \\
& & DFL & 0.01084 & 0.00646 & $\mathbf{0 . 0 9 7 1}^{* *}$ \\
\hline REM & 0.0314 & DEL & 0.00414 & 0.00061 & $\mathbf{0 . 0 0 0 0}^{*}$ \\
& & DOL & 0.00827 & 0.00535 & 0.1256 \\
& & DFL & 0.00961 & 0.0029 & $\mathbf{0 . 0 0 1 3}^{*}$ \\
\hline
\end{tabular}

Source: Data processed where: *significant at the real level of 5\%, ${ }^{* *}$ significant at the real level of $10 \%$. 


$$
\beta \text { property }=1.29601+0.00414 D E L+0.00827 D O L+0.00961 D F L
$$

Based on Table 3 above the DEL variable has a positive effect on the real level of $5 \%$ or directly proportional to the systematic risk of stocks. The DEL variable has a probability value of 0.0000 with a coefficient of 0.00414 . This result shows that every increase of 1 unit of DEL, it will make the systematic risk of all issuers in the model increase by 0.00414 units. The results of this coefficient are in accordance with the theory and hypothesis proposed in this study, in which the hypothesis in this study is that DEL has a positive effect on systematic risk. The regression results of this study indicate the same conditions as the research conducted by Grifin and Dugan (2003) which showed a positive relationship between DEL and systematic risk in the issuers of manufacturing sub-sectors.

This finding indicates that the value of DEL can increase the value of the systematic risk of stocks in the property sector companies, which is indicated by the DEL value that has a significant positive effect. These findings indicate that changes in sales due to changes in inflation can explain systematic risk. If inflation experiences high volatility, then there is a possibility of greater sales volatility which results in uncertainty in the profits earned by the company. The uncertainty of profit obtained by the company will ultimately increase the systematic risk of stocks in the property sector companies. Inflation movement to sales level of property sector companies can be seen in Figure 3.

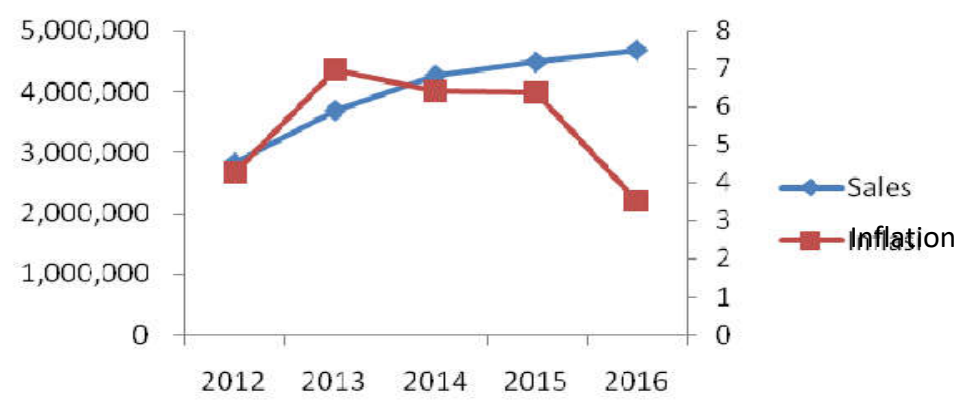

Figure 3 - Sales and inflation property sector

Based on Table 3 above the DOL variable has a positive effect or is directly proportional to the systematic risk of stocks. DOL variable has a probability value of 0.1256 with a coefficient value of 0.00827 . These results indicate that every increase in 1 unit of $\mathrm{DOL}$, so that the systematic risk of all issuers in the model will increase by 0.00827 units. The results of this coefficient are in accordance with the theory and hypothesis proposed in this study, in which the hypothesis in this study indicate that DOL has a positive effect on systematic risk. The regression results of this study showed the same conditions as the researchs conducted by Putri Hervie Karuniandari (2006), Kartini and Nevsi Rizki Herine Putri (2008), and Bram Hadianto and Lauw Tjun Tjun (2009) which showed a positive relationship between DOL and systematic risk on issuers of manufacturing and mining subsectors.

This finding indicates that the DOL value can increase the value of stocks systematic risk in the property sector companies, which is marked by a positive but insignificant DOL value. This condition is not in line with the research conducted by Grifin and Dugan (2003). This finding indicates that EBIT changes because sales changes cannot explain systematic risk. This condition is estimated because a small change in the level of sales does not provide a significant change in the company's operating profit (EBIT), that can be seen in Figure 4. The increase in the level of sales in property sector companies is not proportional to the increase in operational costs.

Based on Table 3 above the DFL variable has a positive effect on the real level of $5 \%$ or is directly proportional to stocks systematic risk. DFL variable has a probability value of 0.0013 with a coefficient value of 0.00961 . These results indicate that for every increase in 1 unit of DFL, it will make the systematic risk of all issuers in the model rise by 0.00961 units. 
The results of this coefficient are in accordance with the theory and hypothesis proposed in this study, in which the hypothesis in this study is that DFL has a positive effect on systematic risk. The regression results of this study indicate the same conditions as the research conducted by Putri Hervie Karuniandari (2006) which showed a positive relationship between DFL and systematic risk in the issuers of manufacturing sub-sectors.

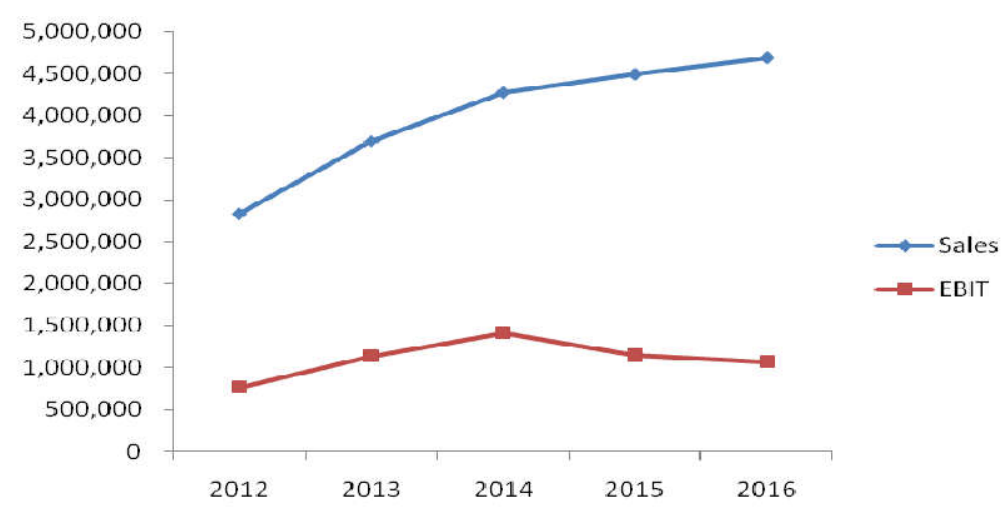

Figure 4 - Sales and EBIT property sector

This finding indicates that the DFL value can increase the value of stocks systematic risk in the property sector companies, which is characterized by a significant positive DFL effect. This finding indicates that EAT changes because EBIT changes can explain systematic risk. This condition is estimated because small changes in EBIT can provide significant changes to the EAT, which can be seen in Figure 5 below.

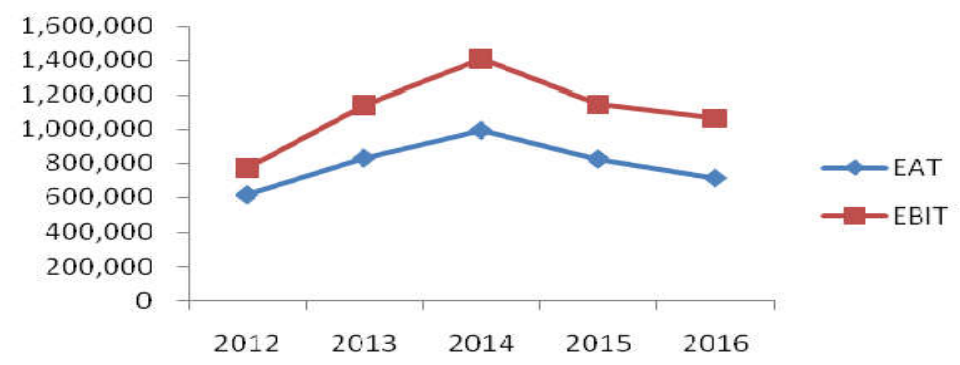

Figure 5 - EAT and EBIT property sector

Table 4 - Panel data regression model results on agriculture sector companies

\begin{tabular}{|c|c|c|c|c|c|}
\hline Model & R-Squared & Variable & Coefficient & Std Error & Prob \\
\hline \multirow[t]{3}{*}{ PLS } & 0.1528 & DEL & -0.0066 & 0.00226 & $0.0084^{*}$ \\
\hline & & DOL & -0.0205 & 0.00542 & $0.0011^{*}$ \\
\hline & & DFL & -0.0526 & 0.05692 & 0.3657 \\
\hline \multirow[t]{3}{*}{ FEM } & 0.29862 & DEL & -0.0012 & 0.0028 & 0.6666 \\
\hline & & DOL & -0.0199 & 0.00438 & $0.0003^{*}$ \\
\hline & & DFL & -0.0115 & 0.06102 & 0.8532 \\
\hline \multirow[t]{3}{*}{ REM } & 0.1528 & $\overline{D E L}$ & -0.0066 & 0.00226 & $0.0084^{*}$ \\
\hline & & DOL & -0.0205 & 0.00542 & $0.0011^{*}$ \\
\hline & & DFL & -0.0526 & 0.05692 & 0.3657 \\
\hline
\end{tabular}

Source: Data processed where: *significant at the real level of $5 \%$, ** significant at the real level of $10 \%$.

$$
\beta \text { agriculture }=0.79489-0.0066 \text { DEL }-0.0205 \text { DOL }-0.0526 \text { DFL }
$$

Based on Table 4 above the DEL variable has a negative effect on the real level of $5 \%$ or inversely proportional to stocks systematic risk. The DEL variable has a probability value of 0.0084 with a coefficient of -0.0066 . This result showed that every increase of 1 unit of $\mathrm{DEL}$, it will make the systematic risk of all issuers in the model decrease by 0.0066 units. The results of this coefficient are not in accordance with the theory and hypothesis proposed in 
this study, in which the hypothesis in this study is DEL has a positive effect on systematic risk. The regression results of this study indicate the same conditions as the research conducted by Putri Hervie Karuniandari (2006) which showed a negative relationship between DEL and systematic risk in the issuers of manufacturing sub-sectors.

This finding indicates that DEL value can reduce the value of stocks systematic risk in the agriculture sector companies, which is indicated by DEL value has a significant negative effect. This condition is not in line with the research conducted by Grifin and Dugan (2003). This is because the agriculture sector is the primary sector that is needed by the market, so that inflation volatility does not have a significant effect on sales and changes in obtained profit. This will ultimately reduce stocks systematic risk in the agriculture sector companies. Inflation movement to sales level of agriculture sector companies can be seen in Figure 6 below.

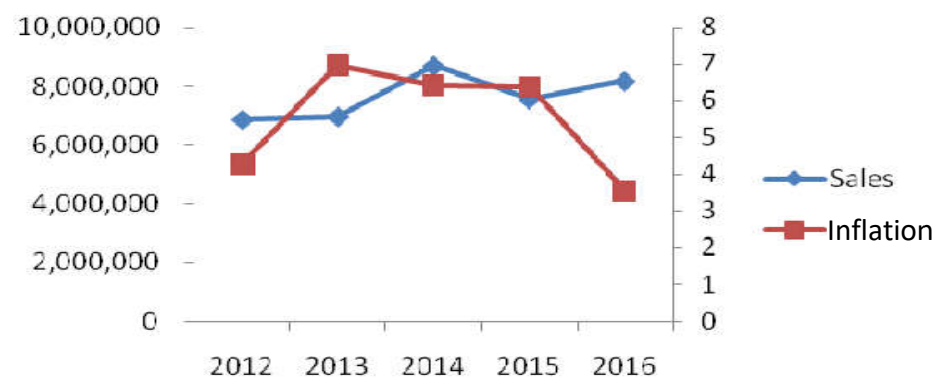

Figure 6 - Sales and inflation agriculture sector

Based on Table 4 above the DOL variable is a negative influence on the real level of $5 \%$ or inversely proportional to the systematic risk of stocks. The DOL variable has a probability value of 0.0011 with a coefficient of -0.0205 . This result shows that every increase in 1 unit of DOL, so that the systematic risk of all issuers in the model will decrease by 0.0205 units. The results of this coefficient are contrary to the theory and hypothesis proposed in this study, in which the hypothesis in this study is DOL has a significant positive effect on systematic risk. The regression results of this study indicate the same condition as the research conducted by Griffin and Dugan (2003) which showed a negative relationship between DOL and systematic risk in the issuers of manufacturing sub-sectors.

This finding indicates that the DOL value can reduce the value of the systematic risk of stocks in the agriculture sector companies, which is characterized by a significant negative DOL effect. This finding indicates that EBIT changes because sales changes can explain systematic risk. This condition is estimated because small changes in the level of sales can provide significant changes in the company's operating profit (EBIT), which seen in Fugure 7. Changes in the level of sales in the agriculture sector companies tend to be proportional to the increase in operational costs.

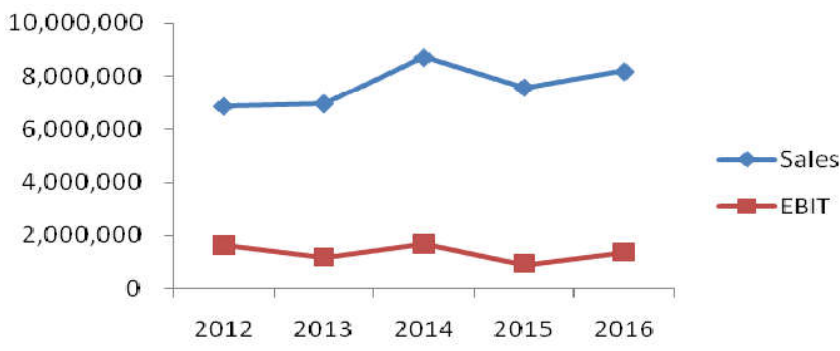

Figure 7 - Sales and EBIT agriculture sector

Based on Table 4 above the DFL variable has a negative effect or inversely proportional to stocks systematic risk. Variable DFL has a probability value of 0.3657 with a coefficient of -0.0526 . These results indicate that for each increase in 1 unit of DFL, it will 
make the systematic risk of all issuers in the model decrease by 0.0526 units. The results of this coefficient are contrary to the theory and hypothesis proposed in this study, in which the hypothesis in this study is that DFL has a significant positive effect on systematic risk. The regression results of this study indicate the same condition as the research conducted by Griffin and Dugan (2003) which showed a negative relationship between DFL and systematic risk in the issuers of manufacturing sub-sectors.

This finding indicates that the DFL value can reduce the value of stocks systematic risk in the agriculture sector companies, which is characterized by a negative but insignificant DFL value. These findings indicate that changes in EAT because changes in EBIT don't affect systematic risk. This condition is caused by the agriculture sector being the primary sector needed by the market, in the end the influence on systematic risk is not significant. EAT movement to EBIT in agriculture sector companies can be seen in Figure 8 below.

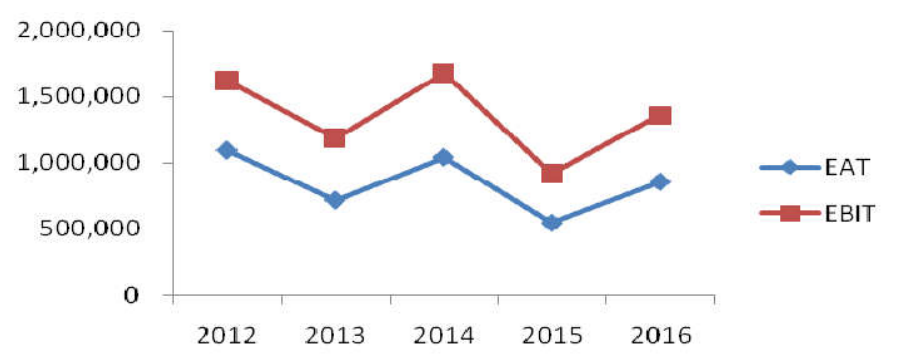

Figure 8 - EAT and EBIT agriculture sector

\section{MANAGERIAL IMPLICATIONS}

Property sector stocks with an average stock beta value of 1.3 are better investment choice compared to the agriculture sector (with average value is 0.66 ) when market conditions are bullish (experiencing an increase). On the contrary, when market conditions are bearish (decreasing), investors are advised to invest in agriculture sector stocks.

For investors who will or have invested in the property sector, they must pay attention to how the company is able to increase its sales when there is an economic shock and the company's ability to generate profits from the use of external corporate funds in the form of corporate debt funds, because these two factors have a significant positive effect on company's systematic risk. If the company's sales response increases when inflation increases, the property sector remains an alternative investment option during bullish market conditions. On the other hand, if the increase in inflation causes a decrease in the company's sales and the total beta value of the stocks becomes above 1, then the property sector is not an investment choice during bullish conditions. If an increase in the company's EBIT causes a decrease in the EAT of the company and the total beta value of the stock becomes above 1 , the property sector is an investment choice when the condition is bearish. On contrary, if the company's EAT response increases when there is an increase in the company's EBIT, the property sector remains an alternative investment option during bullish market conditions. Therefore, during a bullish market condition investors are advised to invest in property sector companies stocks that are experiencing increased sales and/or experiencing increased aftertax income.

For investors who will or have invested in the agriculture sector, they must pay attention to how the company's ability to generate sales when there is an economic shock and the company's ability to generate profits from the company's fixed costs. If the company's sales response increases in the event of an increase in inflation, the agriculture sector remains an alternative investment option when the market conditions are bearish. On the other hand, if the increase in inflation causes a decrease in sales of the company and the total beta value of the stock becomes above 1, then the agriculture sector is not an investment choice in bearish conditions. If the company's sales increase causes a decrease in the company's EBIT and the total beta value of the stocks becomes above 1, then the agriculture sector is an investment choice during bullish conditions. On the contrary, if the 
company's EBIT response increases when there is an increase in company sales, the agriculture sector remains an alternative investment option when market conditions are bearish. Therefore, during bullish market conditions, investors are advised to invest in agriculture sector companies that are experiencing increased sales and/or expanding their business.

\section{CONCLUSION}

Based on study results in the property sector, only DEL and DFL variables that have a significant positive effect on the systematic risk of stocks, while the DOL variable doesn't have a significant effect on systematic risk. In the agriculture sector, only the DEL and DOL variables have a significant negative effect on the systematic risk of stocks, while the DFL variable doesn't have a significant effect on systematic risk. Changes that occur in the DEL and DFL variables in the property sector when there is an increase will increase systematic risk. Changes that occur in the variables DEL and DOL in the agriculture sector when there is an increase will reduce systematic risk.

\section{SUGGESTIONS}

For investors, it's expected to pay more attention to the value of DEL, DOL, and DFL because these three values can affect systematic risk. This is also to minimizing risk as well as maximizing profits. For companies, because it is proven that DEL, DOL, and DFL variables have an influence on systematic risk, the company should make a strategy to control systematic risk to gain investors' trust in investing. For the next researcher, it is better to add other independent variables that is expected to give more accurate influence in analyzing factors that influence systematic risk, these variables include: changes in interest rates, economic growth, political conditions, exchange rates. In addition, add more company sectors and research periods.

\section{REFERENCES}

1. Bodie, Z., Kane, A., Marcus, A.J., 2008. Investments. Eighth Edition. The McGraw-Hill: New York.

2. Griffin HF, Dugan MT. 2003. Systematic risk and revenue volatility. The Journal of Financial Research. 25(2):179-189.doi:10.1111/1475-6803.00053.

3. Hadianto B, Tjun LT. 2009. Pengaruh leverage operasi, leverage keuangan, dan karakteristik perusahaan terhadap risiko sistematik saham: studi empirik pada emiten sektor pertambangan di bursa efek Indonesia. Journal of Accounting. 1(1):1-16.

4. Kartini, Putri NRH. 2008. Pengaruh level leverage operasi dan level leverage keuangan terhadap risiko sistematis (studi kasus pada perusahaan manufaktur). APLIKASI BISNIS. 7(9).doi:10.20885/jabis.vol7.iss9.art6.

5. Karuniandari PH. 2006. Analisis degree of economic leverage (DEL), degree of operating leverage (DOL), dan degree of financial leverage (DFL) terhadap risiko sistematis di Bursa Efek Jakarta [thesis]. Yogyakarta (ID): University of Gadjah Mada.

6. Mandelker GN, Rhee SG. 1984. The impact of the degrees of operating and financial leverage on systematic risk of common stock. The Journal of Financial and Quantitative Analysis. 19(1):45-57.doi:10.2307/2331000. 